\title{
See No Evil? Revisiting Early Visions of the Social Responsibility of Business: Adolf A. Berle's Contribution to Contemporary Conversations
}

\author{
Erika George
}

\section{INTRODUCTION}

The rise of the modern corporation has brought a concentration of economic power which can compete on equal terms with the modern state. ${ }^{1}$

\section{$\sim$ Adolf A. Berle}

Consider the following three scenarios:

(1) The Pharmaceutical Manufacturers' Association of South Africa, a coalition of the local subsidiaries of a number of major multinational pharmaceutical corporations, challenges the South African government's legislative efforts to increase access to medicines. In a lawsuit filed in the South African High Court, the corporations argue that the proposed reforms would constitute a violation of their property rights. ${ }^{2}$ South Africans living with HIV and AIDS oppose the industry lawsuit asserting that corporations place at risk their rights to health, dignity, and life. ${ }^{3}$ Street protests against "profiteer-

\footnotetext{
${ }^{\dagger}$ Professor of Law, University of Utah S.J. Quinney College of Law. B.A. University of Chicago; M.A., University of Chicago; J.D., Harvard Law School. The author thanks Charles O'Kelley, participants in the inaugural symposia of the Adolf A. Berle, Jr. Center on Corporations, Law and Society at Seattle University School of Law, and the Berle family. The author also thanks John Flynn for his helpful comments, Razvan Ungureanu, Ronald Fuller and John Bevan for their excellent research assistance, and Jennifer Ku for her assistance in preparing this Article.

1. Adolf A. Berle, Jr. \& Gardiner C. Means, The Modern Corporation and Private PROPERTY, 357 (1934).

2. Henri E. Cauvin, Access to AIDS Drugs at Issue in South African Trial This Week, N.Y. TIMES, Mar. 5, 2001, at A7, available at http://www.nytimes.com/2001/03/05/world/access-to-aidsdrugs-at-issue-in-south-african-trial-this-week.html?scp=1\&sq=Access \%20to\%20AIDS\%20Dru gs\%20at $\% 20$ Issue $\% 20 I n \% 20$ South\%20African\%20Trial\&st=cse. See also Sarah Joseph, Pharmaceutical Corporations and Access to Drugs: The "Fourth Wave" of Corporate Human Rights Scrutiny, 25 HUM. RTS. Q. 425, 443 (2003); Jennifer Joni, Access to Treatment for HIV/AIDS: A Human Rights Issue in the Developing World, 17 CONN. J. INT'L L. 273, 276-77 (2002).

3. David Barnard, In the High Court of South Africa, Case No. 41238/98: The Global Politics of Access to Low-Cost AIDS Drugs in Poor Countries, 12 Kennedy Inst. ETHICS J. 159, 165
} 
ing pharmaceutical empires" start in South Africa and gain solidarity supporters around the world. ${ }^{4}$ The corporate coalition elects to drop the lawsuit after losing in the court of international public opinion. The conflict comes to be understood as a contest between the "private interest of the pharmaceutical industry" and "people's lives and the public interest.",

(2) Nigerian environmental activists allege that activities of a corporation engaged in oil exploration and extraction are damaging ecological systems and disrupting traditional ways of life. While activists engage in acts of civil disobedience and destroy equipment, the corporation's executives demand protection for the industry's investments and operations in the area. The Nigerian military government uses violent force to protect property. Eventually, the conflict escalates ending in the execution of a prominent community activist. $^{6}$ Litigation later brought in a United States Federal District Court alleges corporate complicity in the human rights violations visited upon environmental activists by the government.

(3) A pro-democracy activist in China is arrested and imprisoned. An electronic correspondence, which he assumed was transmitted in confidence to a U.S. based human rights organization, was intercepted by the Chinese state security apparatus, surrendered by an Internet media and communications corporation. ${ }^{8}$ Chinese state security forces in turn identify the activist based on information provided by the corporation. ${ }^{9}$ The activist remains imprisoned and the corporation involved is widely criticized for its complicity with the Chinese government in violating the activist's human rights. ${ }^{10}$

In each of these instances, what does responsible corporate conduct require? What is evil? What are the corporation's obligations and to whom does the corporation owe these obligations? What options are

(2002); Nathan Geffen, Applying Human Rights to the HIV/AIDS Crisis, CARNEGIE COUNCIL, May 6, 2001, http://www.cceia.org/resources/publications/dialogue/2_06/articles/646.html (last visited April 23, 2010).

4. Cauvin, supra note 2.

5. Tshimanga Kongolo, Public Interest versus the Pharmaceutical Industry's Monopoly in South Africa, 4 J. WORLD INTELL. PROP. 609, 610 (2001); Barnard, supra note 3, at 165.

6. Jedrzej George Frynas, The Oil Industry in Nigeria: Conflict Between Oil Companies and Local People, in Transnational CORPORATIONS AND Human Rights 99 (Jedrzej Gorge Frynas \& Scott Pegg eds. 2003).

7. Isabel Ordonez, Shell Settles Nigeria Case, WALL St. J., June 9, 2009, at B2; Wiwa v. Royal Dutch Petroleum Co., 226 F.3d 88 (2d Cir. 2000).

8. Mure Dickie \& Richard Waters, Yahoo Accused of Helping China Convict Journalist, Fin. TiMES, Sept. 7, 2005.

9. Joseph Kahn, Yahoo Role Documented in Chinese Trial, N.Y. TIMES, Sept. 8, 2005, at C11, available at http://www.nytimes.com/2005/09/08/technology/08yahoo.html.

10. Id. 
available to multinational enterprise, and which options should be exercised when confronted with these or similar situations?

Much corporate legal scholarship considers such fact patterns as beyond the scope of the discipline's core concerns. Yet, increasingly, questions are asked concerning the scale and scope of modern corporate power. This Article will challenge the conventional understanding of what the core discipline of corporate law should encompass and argues that the failure to focus on precisely these sorts of factual scenarios involving allegations of corporate complicity in human rights violations and environmental degradation is misguided and short-sighted.

This Article situates Adolf A. Berle's contribution to the field of corporate law in the context of current debates over the alleged complicity of multinational corporations in international human rights violations. Specifically, this Article revisits some central insights offered by Berle and Gardiner C. Means in The Modern Corporation and Private Property and reconsiders what conducting business consciously across borders requires in the context of a governance gap generated by economic globalization. Further, this Article considers how both ownership and control are well situated to ensure that business conduct becomes better aligned with a growing consciousness that business organizations must respect human rights and protect the environment, or risk reputational harm. This Article concludes by asserting that the dominant approach to the study of corporate law, with its emphasis on internal governance and the relationship between ownership and control, must be dislodged to create space for additional inquiry focusing on the external effects of the modern corporation and its relationship to society.

By revisiting some of the insights offered by Berle, this Article reviews how his insights might inform international human rights advocacy and corporate social responsibility in cross-border contexts. This Article proceeds in three parts. Part I describes how Berle's groundbreaking work, The Modern Corporation and Private Property, was received at the time of its publication, and its treatment over time. In addition, Part I also reviews the relevant portions of The Modern Corporation and Private Property that could serve to further advance the consciousness underlying contemporary efforts to demand corporate accountability for human rights violations. Part II documents how human rights advocates have criticized corporate conduct and increasingly asserted claims against corporations for alleged complicity in human rights violations and environmental damage over the past several years. Finally, Part III offers reflections on how legal scholars might look to Berle's legacy to explain the underlying conditions that can lead to human rights violations where corporate power operates in various governance voids around the 
globe. Part III concludes that, under pressure from the "community," ownership and control can and must consider external effects in order to make choices that are sustainable for the environment and consistent with human dignity.

\section{THE MODERN CORPORATION AND BERLE'S CONTRIBUTION TO CORPORATE SOCIAL RESPONSIBILITY}

Over the course of his professional life, Adolf Berle earned acclaim for a wide variety of achievements. Berle was a successful corporate lawyer, a respected legal scholar, and an early academic prodigy entering Harvard College at age fourteen. ${ }^{11}$ Eventually, Berle went on to become an advisor to President Franklin D. Roosevelt in the "Brain Trust" that masterminded the New Deal's regulatory reforms. ${ }^{12}$ Later in life, Berle was a diplomat and, while serving as Assistant Secretary of State, a leading authority on Latin-American affairs. ${ }^{13}$ In the interim, Berle introduced crucially important ideas concerning the nature of concentrated private power-in the form of the modern corporation-and its consequences for the public.

After his death, in addition to his service to presidents of both parties since Woodrow Wilson, Berle was remembered for his committed public service, from his position on the delegation staff at the Versailles Peace Conference after World War I, to his efforts to establish the nascent United Nations. ${ }^{14}$ In academic circles, Berle is remembered for his contribution to corporate legal scholarship. Awarded an interdisciplinary grant from the Laura Spelman Rockefeller Foundation in 1927, at the recommendation of Edwin Gay, an economic historian and the founding Dean of the Harvard Business School, Berle, in cooperation with Columbia University economist Gardiner E. Means, undertook a comprehensive study of the corporation combining the perspectives of their respective disciplines. ${ }^{15}$ Published in 1932, the resulting text, The Modern Corpo-

11. Jordan A. SCHWARZ, LIBERAL: AdOLF A. BERLE AND THE ViSION OF AN AMERICAN ERA 13 (1987).

12. Albin Krebs, Adolf A. Berle Jr. Dies at Age of 76: Lawyer, Economist, Liberal Leader Aided Presidents, N.Y. TIMES, Feb. 19, 1971, at A1. As a member of the FDR brain trust, Berle was credited with framing the New Deal social programs to appeal to the moderate middle of the nation.

Id. He believed, "It is possible . . that all the social inventiveness of the world was not exploded between the two poles of Adam Smith and Karl Marx." Id.

13. Id.

14. Obituary, Adolf A. Berle Jr., N.Y. TIMES, Feb. 20, 1971. ("Brilliant, articulate and aware of his own impressive attributes, he could have played the role of eminence grise, but his was too shimmering a character to be thought of as any shade of gray . . . Here was that rare resource-a fine mind devoting its great talent to the city, to the nation and to humanity.").

15. Thomas K. McCraw, In Retrospect: Berle and Means, 18 REV. AM. Hist. 578, 579 (1990). 
ration and Private Property, received critical acclaim, as well as a considerable amount of criticism.

Fundamentally, The Modern Corporation and Private Property presented a challenge to the traditional logic of property and profits by pointing out two powerful phenomena: the concentration of power and the separation of ownership from control over the corporation. After exploring the inadequacies of traditional theory to explain and address the potential consequences of increasingly concentrated commercial power, The Modern Corporation and Private Property advanced a new concept of the corporation, and called for a reorientation of enterprise. ${ }^{16}$

\section{A. Commentary on Berle's Modern Corporation}

At the time of its publication, lawyer Jerome Frank, who would later be appointed to chair the Securities and Exchange Commission, equated The Modern Corporation to Adam Smith's Wealth of Nations. ${ }^{17}$ Historian Charles Beard likened the book to The Federalist. ${ }^{18}$ Commentators and the popular print media celebrated the book. The book was described as "epoch-making" in The Nation. ${ }^{19}$ A review in The New Republic praised the book as "epoch-shattering." 20 Indeed, the original publisher, Commerce Clearing House, fearing reprisals from its overwhelmingly corporate clientele, declined to print the book because of its "critical implications." 21

Business historian Thomas K. McCraw attributed the success of The Modern Corporation and Private Property to its "extended analytical form" and "ingenious mixture of statistics" combining both "highly technical legal argument, and philosophical speculation.,"22 According to McCraw, The Modern Corporation and Private Property was written in a rhetorical style which makes it possible to read as "either as a dispassionate analysis - an exercise in value-neutral social science-or as a manifesto." ${ }^{23}$ Arguably, over the years different audiences have read the book to suit their own preferences and perspectives.

Over time, The Modern Corporation and Private Property was criticized by neoclassical quarters. A 1982 symposium hosted by Stanford's Hoover Institution to commemorate the fiftieth anniversary of The Modern Corporation and Private Property's publication produced a

16. BERLE \& MEANS, supra note 1.

17. McCraw, supra note 15 , at 579 .

18. Id.

19. Id.

20. Id.

21. $I d$. at 581.

22. Id. at 579 .

23. McCraw, supra note 15, at 582. 
number of articles condemning several aspects of the book. For example, Robert Hessen argued that Berle and Means' claims concerning the risks associated with shareholders' surrendering to control "defied common sense." ${ }^{24}$ George J. Stigler and Claire Friedland attributed The Modern Corporation and Private Property's apparently unmerited influence to the "astonishingly uncritical" reception it received from "lawyers (and other amateurs)," despite the book's "inconclusiveness," and the fact that "the actual effects of the separation of ownership and control are left undetermined, and even understudied" in the book. ${ }^{25}$ Nathan Rosenberg credited Berle and Means with identifying "some profound social transformations," albeit with "a peculiar tunnel vision.",26

Reactions to the book, as well as assessments of its role and influence on the body of corporate law, vary. For instance, writing years later, contemporary progressive corporate legal scholar Dalia Tsuk placed part of the responsibility for "the exclusion of workers' interests from corporate law and shareholder centrism" not solely with Milton Friedman. Tsuk also emphasized the general reluctance of "American legal scholars (progressives, moderates and conservatives),"-Berle included- "to accept the existence of a permanent, working, wage-labor class." Tsuk argues that the omission of other interests to the exclusion of the shareholder resulted in a failure to consider class and power differentials. $^{27}$

Basically, Berle is celebrated, criticized, often cited, and, more often, misunderstood. According to Tsuk, amidst the shifting tides of corporate theory, worse perhaps than being "misinterpreted," The Modern Corporation and Private Property has been "functionally rewritten." 28 Tsuk argues that subsequent scholars have distorted the book's discussion of the separation of ownership from control to justify a shareholdercentered vision of managerial obligations to the exclusion of other interests. ${ }^{29}$ Indeed, important aspects of Berle's work that could have expanded the core concerns of the study of corporate law have fallen out of favor.

24. Robert Hessen, The Modern Corporation and Private Property: A Reappraisal, 26 J. L. \& ECON. 273, 288 (1983)

25. George J. Stigler \& Claire Friedland, The Literature of Economics: The Case of Berle and Means, 26 J. L. \& ECON. 237 (1983).

26. Nathan Rosenberg, Comments on Robert Hessen, "The Modern Corporation and Private Property: A Reappraisal," 26 J. L. \& ECON. 291, 291 (1983).

27. Dalia Tsuk, Corporations Without Labor: The Politics of Progressive Corporate Law, 151 U. PA. L. REV. 1861, 1863 (2003).

28. Dalia Tsuk, From Pluralism to Individualism: Berle and Means and 20th Century American Legal Thought, 30 LAW \& SOC. INQUIRY 179, 209 (2005).

29. Id. at 180 . 
Nevertheless, The Modern Corporation and Private Property remains relevant and one of the most cited works in legal scholarship. ${ }^{30}$ According to William W. Bratton, Berle's scholarship survives because he "diagnosed a persistent condition . . . problems left untreated both then and now." 31 McCraw attributes The Modern Corporation and Private Property's lasting influence to the profound questions it raised:

Many thousands of nonfiction books appear annually in the United States. Most encounter a cosmic apathy. Some become standard references and are consulted by specialists for years afterward. A tiny handful - two or three per decade - raise penetrating and persistent questions in some memorable way. They become classics, to be cited, if not necessarily read, for generations into the future. The Modern Corporation and Private Property is such a classic. . . . It etched two powerful ideas-industrial concentration and the separation of ownership and control - into the thoughts of a broad body of intellectuals, and thereby gained a permanent place in the life of the mind. ${ }^{32}$

In the academic imagination, Berle's The Modern Corporation and Private Property is remembered primarily for the attention it drew to the economic risks associated with the separation between ownership and control in large publicly traded companies. Equally important, however, was its observations about the concentration of power within large publicly traded corporations. More significant, for informing contemporary conversations about the social responsibility of business, was the book's call for consideration of the interests of the community by powerful corporate actors.

\section{B. Berle's Contribution to Modern Corporate Law}

Exploration of the economic risks that could accompany the separation of ownership from control, as was increasingly characteristic of larger corporations at the time Berle wrote, remains, perhaps, the most well known aspect of The Modern Corporation and Private Property. ${ }^{33}$ However, the text's more significant contribution was its central observation that the corporate form was in the process of a revolutionary transition; a transition that could provide the corporate form with the power and potential to transform society. In Berle's view, " $[t]$ he corporate form

30. William W. Bratton, Berle and Means Reconsidered at the Century's Turn, 26 J. CORP. L. 737, 739-40 (2001).

31. Id. at 739 .

32. McCraw, supra note 15 , at 592.

33. Tsuk, supra note 27 , at 1882. 
had acquired a larger significance." ${ }^{34}$ He saw that the corporation was "becoming both a method of property tenure and a means of organizing economic life." 35

Hence, for Berle, it was no longer accurate to regard corporations as "merely legal devices" for the facilitation of private business transactions between individuals. ${ }^{36}$ More accurately, certain developments had given rise to a "corporate system." 37 Predicting a "spectacular rise" for the corporate form, Berle envisioned a corporate system that would rival the feudal system in its capacity to influence social relations. ${ }^{38}$ Based on his analysis of economic data, "every indication seems to be that the system will move forward to proportions which would stagger imagination."

Berle attributed the corporation's new power to two developments: the industrial factory system and the system of finance. The industrial factory system brought the labor of a large numbers of workers under a single managerial control. Therefore, the large corporation could enjoy access to scale manufacturing and concentrated power over labor. Simultaneously, financial access to the public capital markets permitted a large number of investors to place their wealth under the same central control.

The Modern Corporation and Private Property made clear that an emerging new aspect of the corporation was its control over significant sums of wealth: "the corporation is a means whereby the wealth of innumerable individuals has been concentrated into huge aggregates and whereby control over this wealth has been surrendered to a unified direction." ${ }^{40}$ What remained less clear was the nature of the new relationship between capital and control, and the societal consequences of these new relationships.

Berle discerned different relationships between the functions inherent in enterprise structure as follows:

In discussing problems of enterprise it is possible to distinguish between three functions: that of having interests in an enterprise, that of having power over it, and that of acting with respect to it. . . Under the corporate system, the second function that of having power over an enterprise, has become separated from the first. The position of the owner has been reduced to that of having a set of legal and factual interests in the enterprise while the group which we

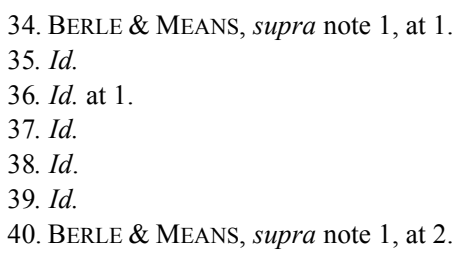


have called control, are in the position of having legal and factual powers over it. ${ }^{41}$

Without legal and factual powers over the enterprise, how would property owners ensure the responsible management and exercise of corporate resources? For Berle, "The property owner who invests in a modern corporation so far surrenders his wealth to those in control of the corporation that he has exchanged the position of an independent owner for one in which he may become merely recipient of the wages of capital." 42

As a result of the changing trend in corporate financing, The Modern Corporation and Private Property explained that the private corporation was giving way to a "quasi public" corporation. Indeed, "the quasipublic corporation commands its supply of capital from a group of investors frequently described as the 'investing public'."43

In an instructive passage, Berle claims that:

By the use of the open market for securities ... corporations assume obligations toward the investing public which transform it from a legal method clothing the rule of a few individuals into an institution at least nominally serving investors who have embarked their funds in its enterprise. New responsibilities towards owners, the workers, the consumers, and the State thus rest upon the shoulders of those in control. In creating these new relationships, the quasipublic corporation may fairly be said to work a revolution. ${ }^{44}$

This revolutionary emerging "quasi public" corporate entity is characterized by proliferation in the number of owners and a significant amount of separation between the ownership of the corporation and those in control. In a key move, Berle argues: "it is precisely this separation of control from ownership which makes possible tremendous aggregations of property." Accordingly, the revolution rested in determining the nature of the responsibilities of control, and its relationship with investors, employees, consumers, society, and the state.

In The Modern Corporation and Private Property, Berle portrayed these developments as a revolutionary departure from the past practices of industry. Rather than being limited by size and controlled by individuals with close relationships to the capital, the modern business orga-

41. Id. at 119-20; McCraw, supra note 15, at 585 (arguing that "the control" for Berle and Means represents "the de facto locus of power, and specifically the power to name the board of directors").

42. BERLE \& MEANS, supra note 1 , at 3.

43. $I d$. at 5 .

44. Id. at 6.

45. Id. at 5. 
nization involved: "aggregations in which tens and even hundreds of thousands of workers and property worth hundreds of millions of dollars, belonging to tens or even hundreds of thousands of individuals, are combined through the corporate mechanism into a single producing organization under unified control and management.",46

The modern corporation was supplanting a system where investors held more of a vested interest in their enterprise because they were more closely connected to their capital. Earlier business organizations typically were owned by individuals or small groups of individuals, and managed personally or by agents. These early businesses were under direct control because the interests of the individual and the interests of the business aligned. ${ }^{47}$ Absent this alignment, Berle feared the risk of divergent interests emerging, potentially to the detriment of owners.

For Berle, the modern corporation was revolutionary because it served to destroy the previously existing assumptions associated with the unity of property through dividing ownership. Such destruction could relocate the seat of power in enterprise. Accordingly, this revolutionary development raised important questions for the future of the corporate form, as Berle explained:

The explosion of the atom of property destroys the basis of the old assumption that the quest for profits will spur the owner of industrial property to its effective use. It consequently challenges the fundamental economic principle of individual initiative in industrial enterprise. It raises for reexamination the question of the motive force back of industry and the ends for which the modern corporation will be run. ${ }^{48}$

As a normative matter, Berle was concerned that management's motives might diverge from owner's interests. Where previously management and ownership were often one and the same, in the emerging corporate form, owners were many and diffuse. Hence, for Berle "ownership continually becomes more dispersed; the power formerly joined to it becomes increasingly concentrated; and the corporate system is thereby more securely established." ${ }^{, 4}$ Berle was deeply concerned with the consequences of the establishment of the type of corporate system his analysis predicted.

The motivations constraining management and counseling the responsible exercise of power were being removed, as the distance between control of operations in the enterprise and the owners of the enter- 
prise increased. Where control and ownership were separate, Berle identified the risk that control would not serve the interests of the owners, but rather its own; becoming self-interested and self-serving. Berle questioned the relationship resulting from "owners without appreciable control and the control without appreciable ownership."50 Whether control would fulfill its obligations to ownership would depend on the degree to which "the self interest of those in control may run parallel to the interests of ownership," and where those interests might differ, checks on power could come from political, economic, or social demands. ${ }^{51}$

After portraying the developments that placed the modern corporation in a potentially revolutionary position, The Modern Corporation and Private Property questioned the consequences of concentrated power and considered possibilities for restraining power. Berle equated the aggregations of power in the enterprise system with the rise of empire: "an economic empire - an empire bounded by no geographical limits, but held together by centralized control." ${ }^{, 52}$ Berle expected the rise of "princes of industry," who would lead the empire of new enterprise and eventually come to occupy positions in society that were yet to be defined. ${ }^{53}$

In a revealing passage, Berle observed:

The rise of the modern corporation has brought a concentration of economic power which can compete on equal terms with the modern state-economic power versus political power, each strong in its own field. The state seeks in some aspects to regulate the corporation, while the corporation, steadily becoming more powerful, makes every effort to avoid such regulation. Where its own interests are concerned, it even attempts to dominate the state. The future may see the economic organism now typified by the corporation, not only on an equal plane with the state, but possibly even superseding it as the dominant form of social organization. The law of corporations, accordingly, might well be considered as a potential constitutional law for the new economic state, while business practice is increasingly assuming the aspect of economic statesmanship. $^{54}$

After exposing the potential risks of concentrated power and the potential to compete with the state, The Modern Corporation and Private Property advocated a new approach to conceptualizing the corporate

50. Id. at 121 .

51. Id.

52. Id. at 3 .

53. Id. at 2 .

54. BERLE \& MEANS, supra note 1, at 357. 
form. The text advanced an alternative and "wholly new concept of corporate activity," where "neither the claims of ownership nor those of control can stand against the paramount interests of the community.",55 In light of the circumstances, Berle recognized that this new conceptualization was needed in order to protect the interests of society and to ensure the responsible exercise of corporate power. ${ }^{56}$

The Modern Corporation and Private Property rejected two ways of ensuring the responsible exercise of power and advanced a new alternative. The first option would be to apply strict property rules to passive ownership and to exercise power for the benefit of security owners. But Berle feared this would result in "the bulk of American industry operated by trustees for the sole benefit of inactive and irresponsible security owners." ${ }^{57}$ Accordingly, Berle rejected the traditional claim that a corporation belongs to its shareholders and "theirs is the only interest to be recognized as the object of corporate activity." 58

The second option would be to treat the corporation under principles of contract. But Berle also rejected this option, because this could leave "a set of uncurbed powers in the hands of control." 59 To Berle, treating security holders as if they had agreed in advance to any losses they might suffer opened the risk of "corporate oligarchy with plundering., 60

Finally, The Modern Corporation and Private Property advanced a new alternative, settling on an understanding of the corporate enterprise as one in which "shareholders by surrendering control and responsibility over the active property, have surrendered the right that the corporation should be operated in their sole interest." 11 This new alternative allowed the corporate enterprise to operate for shareholders, while also taking larger societal conditions into account.

Berle identified the problem of the concentration of power and the divergence of interest. Put another way, Berle pointed out an increasing aggregation of power coupled with the disaggregation of many potentially conflicting interests. He identified inadequacies in traditional theories offering an account of the corporation. Berle argued that the traditional logic of property and profits no longer fit the emerging corporate form. As a result, Berle offered a new concept of the corporation, plac-

55. Id. at 356

56. Id. at $353-54$.

57. Id. at 354 .

58. Id. at 354 .

59. $I d$. at 355

60. Id. at $354-55$.

61. Id. 
ing "the community in a position to demand that the modern corporation serve not alone the owners or the control but all society." 62

\section{The Meaning of Berle's Modern Corporation for Contemporary Corporate Social Responsibility}

Given the increasing power of the corporate system, Berle believed a new and greater responsibility towards a broader segment of society was necessary. To Berle, control did not automatically accrue more power simply because passive owners had surrendered and ceded authority to control. For Berle, the "community" at large now held interest in the actions of the enterprise. The shareholder's surrender of control "cleared the way for the claims of a group far wider than either the owners or the control group; it had placed the community in a position to demand that the modern corporation serve not only the owners or the control group, but all society." ${ }^{\text {,63 }}$ Significant to the contemporary conversation concerning corporate social responsibility, Berle argued that the community could appropriately make demands of industry and that industry should serve society.

An increasingly vocal opposition to corporate conduct that impedes the enjoyment of rights and negatively impacts the environment currently characterizes conversations on corporate social responsibility. Some human rights and environmental activists are calling for binding legal obligations to be placed on corporations. At the same time, some corporations are devoting more resources to voluntary corporate social responsibility initiatives.

In corporate legal scholarship, the conversation over corporate social responsibility dates back to exchanges between Berle and Professor Merrick Dodd on the appropriate exercise of corporate power. ${ }^{64}$ The path for present day debates over corporate social responsibility was first forged in the pages of the Harvard Law Review with the publication of an exchange between Berle and Dodd considering which interests the corporation should serve and how to constrain corporate power.

In his Corporate Powers as Powers in Trust, Berle addressed the problem of managerial excesses and the risk of exercising power contrary to the interests of shareholders. Then, Berle's primary concern was providing a means to protect dispersed and disorganized masses of shareholders. In the article, Berle advanced a theory of managerial re-

62. BERLE \& MEANS, supra note 1 , at 356.

63. Id. at 355 .

64. C.A. Harwell Wells, The Cycles of Corporate Social Responsibility: An Historical Retrospective for the Twenty-First Century, 51 U. KAN. L. REV. 77, 98 (2002). 
sponsibility in which management must exercise its power for "the ratable benefit of shareholders." 65

The following year, Dodd's For Whom Are Corporate Managers Trustees? rejected the shareholder primacy argument advanced by Berle. Dodd argued that the corporation should be conceptualized as a distinct legal persona in which corporate directors would be recognized not as trustees for the shareholders, but as trustees for the corporation in its own right. ${ }^{66}$

Berle and Dodd differed over strategies for constraining corporate power. Although Berle preferred a structure that protected shareholders against power excesses and Dodd presented a picture of an ethical managerial elite that could be trusted to act responsibly, both recognized the opportunities presented by the separation of ownership from control. Both Berle and Dodd appreciated the importance of shareholder protection, as well as the important interests that could be advanced by concentrated corporate wealth in the service of additional constituencies. ${ }^{67}$

In later years, both men would evolve in their thinking and approach the question of corporate social responsibility in ways that departed from their initial positions:

Berle had realized that the implications of The Modern Corporation and Private Property were that running a corporation solely for the benefit of its shareholders was no longer enough. The corporation wielded too much power, and shareholders had too tenuous a tie to their property, to justify such an overriding duty. Dodd, meanwhile, had become disenchanted with the notion that corporations could on their own assume a new role. Only government action, he concluded could impose on corporate management the responsibilities he believed they owed. ${ }^{68}$

C.A. Harwell Wells suggests that, from this vibrant start, legal debates over corporate social responsibility would continue, but not necessarily move forward. Wells argued that, "each new round of debate on corporate social responsibility largely recapitulates the earlier debate[s] in a slightly altered form." ${ }^{69}$ Put simply, the corporate social responsibility debate "rarely seems to go anywhere.",70

65. Id.; see also A.A. Berle, Jr., Corporate Powers as Powers in Trust, 44 HARV. L. Rev. 1049 (1931).

66. Wells, supra note 64, at 98; see also E. Merrick Dodd, Jr., For Whom Are Corporate Managers Trustees?, 45 HARV. L. REV. 1145 (1932).

67. Wells, supra note 64 , at 96.

68. Id. at 98.

69. Id. at 79 .

70. Id. 
The corporate social responsibility debate, or some form of it, will be with us far into the future, unless and until the claims of the community are so clearly articulated that they cannot be set aside. To the community of corporate legal scholars, the observation that the corporate social responsibility dialogue is destined to return to recapitulating prior points is likely accurate. However, the activities of members of the human rights and environmental advocacy community offer an interesting vantage point from which to view the potential for establishing corporate social responsibility that is not simply a trend, but something sustainable.

In The Modern Corporation and Private Property, Berle also envisioned a time in which industry would encounter claims from social constituencies beyond those within the shareholder class. Berle explained:

[D]emands are constantly put forward that the men controlling the great economic organisms be made to accept responsibility for the well being of those who are subject to the organization, whether workers, investors or consumers. ... In proportion as an economic organism grows in strength and its power is concentrated in a few hands, the possessor of power is more easily located and the demand for responsible power becomes increasingly direct. ${ }^{71}$

Berle indicated that, in the face of increasing demands from society, corporations might be made more responsible:

Just as there is a continuous desire for power, so also there is a continuous desire to make that power the servant of the bulk of the individuals it affects. Absolute power is useful. ... More slow, but equally sure is the development of social pressure demanding that the power shall be used for the benefit of all concerned. This pressure, constant in ecclesiastical and political history is already making its appearance in many guises in the economic field. ${ }^{72}$

Now, pressure is mounting. Anti-globalization protesters view corporate power as a significant problem. Pressure groups protest shareholder meetings and advocate for corporations to be held accountable for human rights abuses in which they are alleged to have been complicit. ${ }^{73}$

The new concept of the corporation envisioned in The Modern Corporation and Private Property can come into existence only when the "claims of the community [are] put forward with clarity and force." 74 Indeed, it could come to pass that: "when a convincing system of community obligations is worked out and is generally accepted, in that mo-

\footnotetext{
71. BERLE \& MEANS, supra note 1 , at 354.

72. Id. at 353 .

73. $I d$. at 356

74. Id. at 356 .
} 
ment the passive property right of today must yield before the larger interests of society." 75 Human rights and environmental activists are shaping the content of the community's claim for the exercise of corporate power to serve broader societal interests.

\section{CORPORATE POWER AND COMPLICITY IN INTERNATIONAL HUMAN RIGHTS ABUSES}

This Part describes the traditional scope of international law and explains how changes in global markets and geopolitics have led to calls to expand the scope of international law. This Part also discusses the conceptual challenges for public international law presented by globalization and private actors - the multinational corporation in particular. In response to this challenge, recent public advocacy efforts and public interest litigation have emerged to impose human rights obligations on multinational corporations, both in theory and in practice.

Allegations are increasing that multinational corporations are directly engaging in human rights violations or are aiding and abetting the efforts of repressive governments to abuse human rights. International human rights law has conventionally placed a primary emphasis on abuses perpetrated by governments and the relationship between states and individuals (protecting individual rights from state intrusion). Contemporary human rights advocacy groups and others are now directing greater attention to questioning the role of private non-state actorsprincipally multinational corporations - in conduct that contravenes generally accepted principles of international human rights law. As Berle predicted, certain communities now claim that the interests of industry must yield to the larger interests of society.

\section{A. The Scale and Scope of the Power of the Modern Multinational Corporation}

In The Modern Corporation and Private Property, Berle equated the emerging power of enterprise to an empire; an economic empire that knows no geographic restrictions, and could possibly come to rival the state in its influence over social relations. Indeed, industry today enjoys an expansive reach. Unified corporate organizations operate across borders and are present in many different countries. The organization of modern manufacturing has become more globalized, and a corporation may be present or hold interests in many different countries. Some of the world's largest corporations hold significantly more wealth than some of the countries in which they operate. 
The scale and scope of some of the world's largest companies bring salience to Berle's early observations equating enterprise with empire. For example, in 2008, retail giant Wal-Mart's revenue of $\$ 406$ billion made it larger than the economies of all but the world's twenty-five richest countries, ranking ahead of Israel, Portugal, and New Zealand. ${ }^{76}$ Oil giant Exxon ranks not only ahead of Wal-Mart, but its revenues also exceed the gross domestic product of most of the countries in which it operates, including Nigeria, Venezuela, Ecuador and Sudan. ${ }^{77}$ The combined profits of the coalition of pharmaceutical companies which sued South Africa far exceeded the country's gross domestic product. ${ }^{78}$

An increased potential to advance or undermine respect for the protection of human rights and the environment accompanies the greater power of the modern multinational corporation. ${ }^{79}$ Accordingly, the expansion of corporate power around the world raises a question reminiscent of that posed by Berle in The Modern Corporation and Private Property: specifically, how to control the exercise of corporate power.

Human rights activists and others are asking how to bring the conduct of corporations into alignment with human rights standards, and how to hold corporations accountable when their conduct deviates from respect for human rights. ${ }^{80}$

Under international law, governments assume obligations to protect and respect human rights. It is therefore incumbent upon the state to ensure that all actors within the state's territorial borders or under the state's jurisdiction and control comply with laws enacted to protect human rights. However, in light of the shifting power relationships between the state and the corporation that Berle so astutely predicted, the picture is more complicated with respect to a state's responsibility to ensure that corporations respect human rights.

Several factors complicate the conventional relationship between the state and the modern multinational corporation, including the fact that some poorer states are not as economically powerful as the multina-

76. See Aaron Smith, Exxon Mobil Tops Fortune 500: Big Oil Knocks Wal-Mart out of First Place,CNN MONEY.COM, Apr. 21, 2009, available at http://money.cnn.com/2009/04/15/news/ companies/fortune500/index.htm?section=money_latest. For a 2008 list of several country's gross domestic products, see WORLD BANK, GRoss DOMESTIC PRODUCT 2008 (2010), http://siteresources.worldbank.org/DATASTATISTICS/Resources/GDP.pdf.

77. See Smith, supra note 76; WORLD BANK, supra note 76.

78. Joseph, supra note 2, at 444.

79. See, e.g., Jessica Woodroffe, Regulating Multinational Corporations in a World of Nation States, in HumAN RIGHTS STANDARDS AND THE RESPONSIBILITY OF TRANSNATIONAL CORPORATIONS 131, 132 (Michael K. Addo ed., 1999).

80. See, e.g., Thom Hartmann, Unequal Protection: The Rise of Corporate DOMINANCE AND THE THEFT OF HUMAN RIGHTS (2002). 
tional corporations they host. ${ }^{81}$ Compliance and enforcement procedures can be expensive and exceed the available resources of poor and developing states. ${ }^{82}$ Moreover, even where a poorer country would be able to enact and enforce compliance with human rights standards, the country may be unwilling to do so because the mobility of capital in the competitive context of a global economic system would place the state at risk of losing investment from foreign corporations. ${ }^{83}$ Instead of protecting its citizens with stronger enforcement of environmental and human rights protections, the state may elect to promote foreign investment and reject increasing regulation to the extent that investors are perceived to favor environments with lower regulatory standards. ${ }^{84}$

Globalization - the term applied to describe a social, economic and political phenomenon characterized by market-driven expansion and acceleration of exchange across borders ${ }^{85}$ - presents a challenge to the conceptual foundations of international law, as premised on state action and responsibility. Global governance has not kept pace with economic and social changes. ${ }^{86}$ This gap in global governance has fundamentally changed the dynamics of interactions between states and non-state actors.

\section{B. The Conceptual Challenge of the Modern Multinational for State Sovereignty and the State of International Law}

Just as Berle highlighted the conceptual challenge that the corporation presented for the logic of property and profits at the time of his writing, today, the modern multinational corporation presents a comparable challenge to the logic of international law. ${ }^{87}$ Prior to World War II and

81. HENRY J. STEINER, PHILIP Alston, \& RyAn GOODMAN, INTERNATIONAL HuMAN RightS IN CONTEXT: LAW, Politics, Morals 1388 (3d ed. 2008).

82. Id.

83. Id.

84. Id.; David Kinley, Civilising Globalization: Human Rights and the Global ECONOMY 145-203 (2009).

85. See generally, Joseph E. Stiglitz, Making Globalization WORK (2007); JAGDish Bhagwati, In DEFEnSE of Globalization (2004); see also, Joel P. TRACHTMAn, The ECONOMiC StRUCTURE OF INTERNATIONAL LAW (2008); see also, Paddy O-Reilly \& Sophia Tickell, Globalization TNCs and Social Issues in the Developing World, in HuMAN RIGHTS STANDARDS AND THE RESPONSIBILITY OF TRANSNATIONAL CORPORATIONS 273-285 (Michael K. Addo ed., 1999).

86. See generally, JANET Dine, COMPANiES, InTERnATIONAL TRADE AND Human Rights (2005) (investigating the role played by corporations in the failure of globalization and of international trading regimes to meet expectations).

87. See generally, JENNIFER A. ZERK, MUlTINATIONALS AND CORPORATE SOCIAL RESPONSIBILITY: LIMITATIONS AND OPPORTUNITIES IN INTERNATIONAL LAW (2006); FLORIAN WETTSTEIN, MULTINATIONAL CORPORATIONS AND GLOBAL JUSTICE: HuMAN RigHTS OBLIGATIONS OF A QUASI-GOVERNMENTAL INSTITUTION (2009); Nicola Jagers, The Legal Status of the Multinational Corporation Under International Law, in HUMAN RIGHTS STANDARDS AND THE RESPONSIBILITY OF TRANSNATIONAL CORPORATIONS 259-269 (Michael K. Addo ed., 1999); Mah- 
the creation of international multilateral institutions such as the United Nations in 1945, classic international law was literally the "law of nations," made by and for states to govern relationships between sovereigns. ${ }^{88}$ States were the sole "subjects" of international law and were imbued with "international legal personality." ${ }^{89}$ With international legal personality, states enjoy full participation in the international legal system by virtue of possessing the capability to exercise rights and observe duties under international law. Under the classical view of international law, all other entities, such as private non-state actors, were merely "objects." 90

Non-state actors were acted upon, not actors in the international system. In contrast, states, as subjects of international law, enjoyed the right to engage in war, enter into treaties, form consensual rules of international behavior, claim for breaches of international legal obligations, and seek remedies.

After World War II, an international system aimed at the protection and promotion of international human rights was created in an effort to ensure that the atrocities committed during the war should never be allowed to recur. The concept of international human rights gave the individual rights against the state, divesting the state of its absolute, impenetrable, and unchallenged sovereignty.

Today, large and powerful private actors operating in and across many nations - specifically, multinational corporations-pose a significant conceptual and practical challenge to international law. ${ }^{91}$ The classic state-centered view of international law is increasingly difficult to reconcile with the growing number of private, non-state actors who have a significant impact on both states and individuals internationally. Traditional approaches to international law are no longer descriptively or conceptually adequate.

The process of economic globalization, fueled by private enterprise, is eroding the hegemonic place of the state as the subject and source of

mood Monshipouri, Claude E. Welch, Jr. \& Evan T. Kennedy, Multinational Corporations and the Ethics of Global Responsibility: Problems \& Possibilities, 25 HuM. RTS. Q. 965, $965-89$ (2003).

88. LORI F. DAMROSCH, ET AL., INTERNATIONAL LAW: CASES \& MATERIALS 2 (5th ed. 2009).

89. Id. For a discussion of legal personality and recognition in international law, see Ian Brownlie, Principles of Public InTERnational LaW 57-68 (5th ed. 1998); $c f$. John J. Flynn, The Jurisprudence of Corporate Personhood: The Misuse of a Legal Concept, in CORPORATIONS AND SOCIETY POWER AND ReSPONSIBILITY (Warren J. Samuels \& Arthur S. Miller eds., 1987) (examining the implications of recognizing corporations as persons and the concept of corporate personhood).

90. DAMROSCH, ET AL., supra note 88, at 299.

91. Steven R. Ratner, Corporations and Human Rights: A Theory of Legal Responsibility, 111 YALE L. J. 443, 443-545 (2001). 
international law. ${ }^{92}$ As a result of globalization, the place where power resides in the international system is growing more diffuse, and authority for traditionally public functions is being ceded to private enterprise.

No longer are states thought to be the only entities implicated in human rights violations. Significantly, corporations are increasingly implicated along with governments in violating human rights. The independent obligation, if any, of multinational enterprise to conform to international human rights standards is far from clear at this stage. ${ }^{93}$ Presently, multinational corporations operate largely unencumbered by the binding public international human rights obligations that states assume either through treaty or custom. There are often regulatory gaps between the standards of the corporation's home country and its host country; therefore, corporate action often occurs in a regulatory void where there is little law to guide business practices abroad.

The global human rights protection and accountability gap highlights a significant theoretical problem in international law. Specifically, public international law, as conventionally conceived, fails to adequately govern the conduct of private non-state actors, such as multinational corporations. In general, international human rights law is created by and binding upon states. Yet, as a practical matter, some multinational corporations control budgets larger than those of the states in which they operate, and have significant power as a result.

The conceptual and regulatory problems that multinational corporations would eventually pose for international law was identified with extraordinary clarity in 1970 by Detlev Vagts, who noted, "the present legal framework [has] no comfortable, tidy receptacle for such an institution." 94 The problem is that a truly international corporation would be one organized by international law. However, in reality, businesses that cross national borders generally take the form of "a cluster of corporations of diverse nationality joined together by common ties of ownership and responsive to a common management strategy.",95

92. See generally, David Kinley, Civilizing Globalization: Human Rights and the GLOBAL ECONOMY (2009).

93. Peter Muchlinski, Corporate Social Responsibility and International Law: The Case of Human Rights and Multinational Enterprises, in THE NEW CORPORATE ACCOUNTABILITY: CORPORATE SOCIAL RESPONSIBILITY AND THE LAW 440 (Doreen McBarnet, Aurora Vioculescu \& Tom Campbell eds., 2007).

94. Detlev F. Vagts, The Multinational Enterprise: A New Challenge for Transnational Law, 83 HARV. L. REV. 739 (1970).

95. Id. For a discussion of features of multinational corporations, see also Peter Muchlinski, MULTiNATIONAL ENTERPRISES AND THE LAW 12-16 (1995). 
Given this structure of multinational enterprise, corporations are able to operate across borders in an accountability deficit, ${ }^{96}$ largely outside the effective supervision or regulatory control of domestic and international law. ${ }^{97}$ Because the multinational corporation is mobile and able to allocate risk through manipulation of its identity, the multinational corporation is able to reconstitute itself between legally distinct, but economically enmeshed, units.

In the absence of international standards binding on private nonstate actors and in the presence of the global human rights protection and accountability gap, a number of efforts are underway to fill the void created by lapses in international human rights coverage. ${ }^{98}$

\section{Corporate Complicity in International Human Rights Violations}

Initially, human rights organizations such as Amnesty International and Human Rights Watch focused their advocacy efforts primarily on the state. However, in recent years, rights groups have expanded their field of vision to include private actors. Rights activists working on social, economic, and cultural rights now highlight the role of private industry in impeding and advancing human rights and no longer limit their monitoring to states and governments.

For example, the mission statement of Human Rights Watch, included in every investigative report the organization publishes, provides: "We challenge governments and those who hold power to end abusive practices and respect international human rights law. We enlist the public and the international community to support the cause of human rights for all."

Whether, and to what extent, private industry needs to respect international human rights law is currently the subject of debate in the

96. Beth Stevens, The Amorality of Profit: Transnational Corporations and Human Rights, 20 BERKELEY J. INT'L L. 45, 45-90 (2002); Phillip I. Blumberg, Accountability of Multinational Corporations: The Barriers Presented by Concepts of the Corporate Juridical Entity, 24 HASTINGS INT'L \& COMP. L. REV. 297, 319 (2001).

97. See Philip I. Blumberg, The Multinational Challenge to Corporation LaW: The SEARCH FOR A NEW CORPORATE PERSONALITY 201 (1993):

The challenge for the world order is the evolution over the years ahead of an international legal machinery to mediate, adjust, and reduce national conflicts and to emerge with a framework that will not only facilitate the imposition of effective governmental controls over the activities of multinational groups, but will encourage the harmonious development of international economic relations.

98. See Christopher Avery, Business and Human Rights in a Time of Change, in LiABILITY OF Multinational Corporations Under InTERnational Law 17 (Menno T. Kamminga \& Saman Zia-Zarifi eds., 2000); Sarah Joseph, An Overview of the Human Rights Accountability of Multinational Corporations, in LIABILITY OF MULTINATIONAL CORPORATIONS UNDER INTERNATIONAL LAW 75 (Menno T. Kamminga \& Saman Zia-Zarifi eds., 2000). 
academy, industry, and government. While the Universal Declaration of Human Rights proclaims that it applies to "all organs of society," the exact nature of corporate responsibility for human rights remains unresolved. However, corporate obligations with respect to human rights and the environment are evolving and emerging ${ }^{99}$ through a combination of efforts on the part of civil society to attach liability to corporate actors, and reactions on the part of corporations to address consumer concerns and respond to public criticism..$^{100}$

\section{Advocacy and Reporting}

While the activities of enterprise have profound effects on the quality of life in all countries and communities, academics and activists are only beginning to explore and understand the ways in which industry can influence human rights and impact the environment. Organizations monitoring human rights are starting to investigate and focus attention on corporations. Rights monitors are now reporting on a range of violations related to the conduct of corporate actors and the inability of individuals to obtain redress for harms they sustain as consequence of corporate conduct.

As more research is conducted, an increasing base of literature is providing a greater understanding and appreciation of the nature and scope of the problems of corporate complicity in violations and the extent of the impact that certain business practices may have on human rights. This research is also forming the basis for social protest movements demanding that corporations exercise power in ways that respects human rights and the environment. ${ }^{101}$ Non-governmental human rights monitors have investigated the role of corporations with respect to a range of rights standards, including: the right to security of the person, ${ }^{102}$

99. Claire Moore Dickerson, Human Rights: The Emerging Norm of Corporate Social Responsibility, 76 TUL. L. REV. 1431, 1457 (2002)

100. See, e.g., Judith Richter, Holding Corporations Accountable: Corporate CONDUCT, INTERNATIONAL CODES, AND CITIZEN ACTION (2001) (tracing opposition to socially irresponsible marketing by the infant food industry abroad and the resulting WHO/UNICEF Code of Marketing of Breastmilk Substitutes).

101. See generally, Human Rights WATCH \& THE CENTER FOR Human RightS AND GLOBAL Justice, On the Margins of Profit: Rights At Risk IN THE Global ECONOMY (2008) (presenting examples from over ten years of Human Rights Watch research reports on "business-related abuses"); Isabella D. Bunn, Global Advocacy for Corporate Accountability: Transatlantic Perspectives from the NGO Community, 19 AM. U. INT'L L. REV. 1265 (2004).

102. Universal Declaration of Human Rights, G.A. Res. 217A, U.N. Doc. A/810, at art. 3 (1948) [hereinafter UDHR] ("Everyone has the right to life, liberty and security of person."). Violations of this right include war crimes, crimes against humanity, genocide, enforced disappearances, extrajudicial killings, rape excessive and lethal use of force, and torture, cruel, inhuman and degrading treatment. $I d$. 
economic and social rights, ${ }^{103}$ civil and political rights, ${ }^{104}$ equality, ${ }^{105}$ labor rights, ${ }^{106}$ and the rights of indigenous people. ${ }^{107}$ The lack of corporate accountability for complicity in human rights violations and the inability of individuals and communities to obtain effective remedy to redress violations are also subjects being explored by various rights watchdog organizations and others.

Human rights reports have found that the right to security of the person, including, specifically, the right to life, and to physical and psychological integrity, have been negatively affected by corporations both directly and indirectly through connections to third parties engaged in violations. $^{108}$ More recently, rights groups have reported direct violations by businesses, including findings that private, U.S.-based corporate contractors at the Abu Ghraib prison in Iraq allegedly tortured detainees under their control. ${ }^{109}$

More frequently than direct involvement, corporations are indirectly implicated in violations because of their relationships with third parties, such as corrupt or repressive government regimes. Human rights activists maintain that when corporations "fail to ensure that their operations do not depend upon, benefit from, or contribute to human rights abuses committed by others," corporations are complicit in violating human rights. ${ }^{110}$

Human rights reports have documented several incidents infringing on the right to security of the person in connection with abuses perpetrated by security forces employed by corporations to protect property and prevent protests near corporate operations. For example, corporations in Indonesia's paper and wood pulp industry employed private se-

103. International Covenant Economic Social and Cultural Rights, 21 U.N. GAOR, Supp. (No. 16) 49, U.N. Doc. A/6316 (1966) (entered into force Jan. 3, 1976) [hereinafter ICESCR].

104. International Covenant on Civil and Political Rights, 21 U.N. GAOR, Supp. (No. 16) 52, U.N. Doc. A/6316 (1966) (entered into force Mar. 23, 1976) [hereinafter ICCPR].

105. UDHR, supra note 102; ICCPR, supra note 103; ICESCR, supra note 104; International Convention on the Elimination of All Forms of Racial Discrimination, G.A. Res. 2106A (XX), U.N. GAOR, 660, U.N.T.S. 195 (1965), (entered into force Jan. 4, 1969) [hereinafter CERD]; International Convention on the Elimination of All Forms of Discrimination Against Women, 34 U.N. GAOR Supp. (No. 21) (A/34/46) at 193, UN Doc. A/RES/34/180 (Dec. 18, 1979), (entered into force Sept. 3, 1981) [hereinafter CEDAW].

106. ICESCR, supra note 103.

107. Declaration on the Rights of Indigenous People, G.A. Res. 61/295, U.N. GAOR, 61st Sess., 107th plen. mtg., U.N. Doc. A/RES/61/295 (Sept. 13, 2007).

108. Human Rights Watch, ON The MARgins OF Profit 1 (2008), available at http://www.hrw.org/en/node/62409/section/1.

109. Human Rights Watch, By the Numbers: Findings of the Detainee Abuse and ACCOUNTABILITY PROJECT, VOL. 18 NO. 2(G) 19-20 (2006), available at http://www.hrw.org/reports/2006/ct0406.

110. HUMAN RighTS WATCH, supra note 108, at 11. 
curity forces that assaulted members of the communities in which the corporations operate. ${ }^{111}$ In southern Sudan, government forces used oil industry infrastructure to launch attacks against civilians, destroying entire communities and displacing hundreds in the context of a civil conflict situation. ${ }^{12}$

Sometimes corporate presence serves to fuel existing conflict in persistently war-torn but resource rich regions. A 2005 report by Human Rights Watch documents how corporations in the extractive industry were implicated in human rights abuses through their connections to various warlords holding control over gold mines in the Democratic Republic of Congo. In exchange for access to gold rich regions in zones of conflict, private corporations provided logistical and financial support to armed groups engaged in war crimes and crimes against humanity. ${ }^{113}$

In the area of socioeconomic rights and environmental degradation, rights groups reported on the conduct of a Taiwanese corporation dumping toxic waste in Cambodia. The waste caused several deaths and degraded environmental conditions compromising the rights of local residents to health. ${ }^{114}$ Reports have also found that pollution from Nigeria's oil industry severely impaired the livelihood of local communities by destroying the food supply and damaging the supply of fresh drinking water. ${ }^{115}$

Multinational corporations can influence enjoyment of the right to food by influencing food security and the food supply. For example, to meet the demands of commercial crops for foreign export, farmers in developing countries are replacing staple foods with non-traditional export products, thereby reducing food availability and placing food security at risk for local residents. ${ }^{116}$ In another example, tobacco producers in developing countries are clearing trees in semi-arid environments to cultivate tobacco to supply an international export market. The tree

111. HuMAN RightS WATCH, Without REMEDY: HuMAN RightS ABUSE AND INDONESIA'S PULP AND PAPER INDUSTRY, VOL. 15, NO. 1(C) 32-44, 57-58 (2003), available at http://www.hrw.org/en/reports/2003/01/06/without-remedy-0.

112. HUMAN RigHTS WATCH, SUDAN, OIL, AND HUMAN RiGHTS 41-42, 65-69, 251-273, 42829 (2003), available at http://www.hrw.org/reports/2003/sudan1103.

113. Human Rights Watch, The Curse of GolD: Democratic RePublic of CONGo 2-3, 58-83 (2005), available at http://www.hrw.org/reports/2005/drc0505.

114. Human Rights WATch, TOXiC Justice: Human Rights, JusticE AND TOXIC WASTE IN CAMBODIA, VOL. 11, NO. 2(C) 6-9, 25-33 (1999), available at http://www.hrw.org/en/reports/1999/ 05/01/toxic-justice.

115. Human Rights WATCh, The Price OF OIL: CoRPorate RESPONSIBILITY AND HumaN Rights Violations in Nigeria's Oil Producing COMMUNities 7, 53-74 (1999), available at http://www.hrw.org/reports/1999/nigeria.

116. Smita Narula, The Right to Food: Holding Global Actors Accountable Under International Law, 44 COLUM J. TRANSNAT'L L. 691 (2006). 
clearing contributes to deforestation and soil erosion, and compromises food production in countries that are already at risk for food shortages. ${ }^{117}$ Five multinational corporations control nearly seventy percent of the world's tobacco production. ${ }^{118}$ Approximately four-fifths of tobacco is now produced in developing countries. ${ }^{119}$

In the area of civil and political rights monitoring, organizations have documented instances of corporations engaging in rights abuses ranging from censorship and surveillance, to discrimination and slavery. In a 2006 report, Human Rights Watch documented how corporations were cooperating in China's system of Internet censorship and surveillance. The report found that multinational corporations not only complied with instructions from the Chinese government that were inconsistent with international human rights standards, but also went further by attempting to anticipate what the Chinese government would want suppressed and blocked an ever-broadening range of expression on the Internet. Companies complicit in censorship of political and religious views and in monitoring dissenting opinions aid the government in violating individual rights to privacy, blocking freedom of opinion and expression, as well as the right to impart and receive information. ${ }^{120}$

Corporate social responsibility rhetoric of industry notwithstanding, international human rights groups maintain that it is "clear that existing efforts to address the impacts of business activities on human rights are insufficient." Accordingly, a coalition of rights groups have called for a U.N. Declaration or other international instrument to "define[] a common benchmark for business conduct.", lated and widely endorsed global standards . . creat[ing] a framework for concerted action to ensure that business behavior around the world is human rights compliant." 122

In the absence of an international agreement and adequate international enforcement of human rights law, however, advocates have turned to other avenues.

117. John Madeley, Big Business, Poor Peoples: The Impact of Transnational CORPORATIONS ON THE WORLD'S POOR 54-55 (1999).

118. Id. at 48 .

119. Id. at 49 .

120. HumAN Rights WATCH, "RACE TO THE BOTTOM": CORPORATE COMPLiCITY IN CHINESE INTERNET CENSORSHIP, VOL. 18, NO 8(C) (2006), available at http://www.hrw.org/en/reports/2006 /08/09/race-bottom.

121. HUMAN RIGHTS WATCH, supra note 108 , at 51.

122. Id. 


\section{Adjudication and Litigation}

In addition to increased reporting to sway sentiment in the court of public opinion, human rights activists have asserted claims in the U.S. federal courts seeking to hold corporations accountable for violations of international human rights law. To date, the primary tool for human rights litigation has been the Alien Tort Claims Act (ATCA). ${ }^{123}$ Passed in 1789, the ATCA authorizes civil lawsuits for monetary damages for injuries sustained due to violations of international law. ${ }^{124}$ The ATCA grants federal jurisdiction over claims by individuals who are not citizens of the United States for torts that violate international law, including torts committed in violation of the law of nations or a U.S. treaty. ${ }^{125}$

Although the ATCA went virtually unused for nearly 200 years, recently the statute has come to form the bedrock of human rights litigation in the United States for torts occurring abroad. ${ }^{126}$ Specifically, human rights activists have filed ATCA claims in an effort to reach the extraterritorial conduct of corporations accused of violating human rights, either directly or indirectly, through collaboration with repressive regimes. ${ }^{127}$

Cases brought under the ATCA were not, as expected by many in industry, dismissed out of hand. Indeed, a number of federal courts entertained the human rights claims of foreign plaintiffs in U.S. federal courts for violations of international human rights law. A growing number of multinational corporations have been forced to defend against allegations of abuse filed in the U.S. and other courts.

Most notably, ATCA cases have been brought against major multinational corporations for a range of human rights violations around the world. Royal Dutch-Shell Oil was sued for its alleged involvement in human rights violations associated with a Nigerian pipeline project. ${ }^{128} \mathrm{~A}$ more recent lawsuit accused Chevron of hiring, transporting, and supervising Nigerian security forces who shot protesters at a Chevron offshore

123. Doreen McBarnet \& Patrick Schmidt, Corporate Accountability through Creative Enforcement: Human Rights, the Alien Tort Claims Act and the Limits of Legal Impunity, in THE NEW CORPORATE ACCOUNTABILITY: CORPORATE SOCIAL RESPONSIBILITY AND THE LAW 148, 151-52 (Doreen McBarnet, Aurora Vioculescu \& Tom Campbell eds., 2007).

124. Beth Stephens, Corporate Accountability: International Human Rights Litigation Against Corporations in U.S. Courts, in LiabiLITY OF MULTINATIONAL CORPORATIONS UNDER INTERNATIONAL LAW 210 (Menno T. Kamminga \& Saman Zia-Zarifi eds., 2000).

125. 28 U.S.C. $\S 1350$ (1789).

126. See generally Joel R. Paul, Holding Multinational Corporations Responsible Under International Law, 24 HASTINGS INT'L \& COMP. L. REV. 285 (2001).

127. Stephens, supra note 124, at 210.

128. Wiwa v. Royal Dutch Petroleum Co., 226 F.3d 88 (2d Cir. 2000) (allegations included complicity in torture and the summary execution of environmental activist Ken Saro-Wiwa). 
oil platform. ${ }^{129}$ Talisman was sued for alleged involvement in human rights abuses in Sudan. ${ }^{130}$ Unocal defended a lawsuit alleging that it engaged in human rights violations in Burma. ${ }^{131}$ The conduct of ExxonMobil in Indonesia led to a lawsuit alleging human rights abuses. ${ }^{132}$ Texaco has been sued for its alleged involvement in human rights abuses in Ecuador. ${ }^{133}$

But ATCA lawsuits are not limited to corporations engaged in extractive industries. Coca-Cola faced allegations that it violated human rights in Columbia. ${ }^{134}$ Fresh Del Monte Produce was sued for allegedly engaging in abusing human rights in Guatemala. ${ }^{135}$ Pfizer was sued for allegedly violating international law prohibiting involuntary medical experimentation on humans in connection with drug trials on children in Nigeria. ${ }^{136}$

Notwithstanding these initial claims, recent precedent has narrowed the range of violations available for ATCA claimants. In Sosa v. Alvarez-Machain, the U.S. Supreme Court limited the ATCA to apply only to crimes of universal jurisdiction; those crimes, such as genocide, that nations have agreed are particularly heinous. ${ }^{137}$ Since Sosa, the ATCA is a somewhat weaker weapon for rights activists to use against corporations engaged in conduct that violates international human rights law. Nevertheless, rights activists still frequently wield the ATCA in efforts to challenge and change corporate conduct.

Lawyers continue to bring claims arising from the complaints and protests of communities in poorer countries. The plaintiffs in most ATCA cases are poor, indigenous, and socially excluded people who are only able to bring claims because of the assistance of cross-border coalitions of lawyers. ${ }^{138}$ Perhaps ironically, the defendants in many of the ATCA lawsuits earn more in revenue annually than the gross domestic products of the countries in which the alleged rights abuses occurred.

129. Bowoto v. Chevron Texaco Corp., 312 F. Supp. 2d 1229 (N.D. Cal. 2004) (allegations of involvement in human rights violations); see also David R. Baker, Winds of Dissent at Chevron, Critics Challenge Oil Company Even as its Profit Soars, S.F. Chron., May 28, 2008, at C1.

130. Presbyterian Church of Sudan v. Talisman Energy, Inc., 2005 WL 2082846 (S.D.N.Y. 2004) (allegations of genocide, crimes against humanity and other violations of international law).

131. Doe v. Unocal Corp., 110 F. Supp. 2d 1294 (C.D. Cal. 2000) (allegations include slavery).

132. Doe v. Exxon Mobil Corp., 393 F. Supp. 2d 20 (D.D.C. 2005).

133. Aguinda v. Texaco, Inc., 142 F. Supp. 2d 534 (S.D.N.Y. 2001).

134. Sinaltrainal v. Coca-Cola Co., 256 F. Supp. 2d 1345 (S.D. Fla. 2003).

135. Aldana v. Del Monte Fresh Produce, N.A., Inc., 416 F.3d 1242 (11th Cir. 2005).

136. Abdullahi v. Pfizer, Inc., 562 F.3d 163 (2d Cir. 2007).

137. Sosa v. Alvarez-Machain, 542 U.S. 692 (2004).

138. Ronen Shamir, Between Self-Regulation and the Alien Tort Claims Act: On the Contested Concept of Corporate Social Responsibility, 38 LAW \& SOC'Y REV. 635, 638 (2004). 
The trajectory of ATCA litigation can be viewed as consistent with Berle's prediction that communities would eventually come to place pressure on the corporate empire and impose obligations on the princes of industry. Professor Ronen Shamir posits that ATCA litigation "represents a new approach on the part of plaintiffs toward [multinational corporations], approximating their obligations and duties to that of national governments and adding new dimensions to current debates about sovereignty, globalization, the legitimate reach of extraterritorial law, and the possibility of global law."139

\section{Adjusting Corporate Conduct and Responsibility}

While human rights and environmental activists have increased advocacy, reporting, and initiated lawsuits, significant segments of the corporate sector have embraced voluntary codes of conduct to govern their business operations. In his 1999 address to the World Economic Forum in Davos, Switzerland, former U.N. Secretary-General Kofi Annan proposed a new United Nations initiative - the U.N. Global Compact - to address the social ills perceived to accompany globalization. Inviting the world's business leaders to join a new system of "shared values and principles" that would put "a human face on the global market place," Secretary-General observed:

Globalization is a fact of life. ... The spread of markets outpaces the ability of societies and their political systems to adjust to them, let alone guide the course they take. History teaches us that an imbalance between the economic, social and political realms can never be sustained for very long. ${ }^{141}$

The Compact seeks to close the human rights protection gap by bridging the divide between global public interests and global private capital through the creation of a partnership between the U.N. (the public system) and multinational enterprise (the private system). The Compact encourages responsible corporate citizenship by engaging business in ameliorating the harms associated with globalization to create "a more sustainable and inclusive global economy." ${ }^{142}$ The Compact enlists the private sector to work with the U.N., in partnership with international

139. Id. (2001).

140. Alexis M. Taylor, The UN and the Global Compact, 17 N.Y.L. SCH. J. HUM. RTS. 975

141. Kofi Annan, U.N. Secretary-General, A Compact for the New Century Address before the World Economic Forum (Jan. 31, 1999), available at http://www.un.org/News/Press/docs/1999/19 990201.sgsm6881.html.

142. United NATions, Corporate Citizenship in the World ECONOMY: THE Global COMPACT, HUMAN RIGHTS, LABOUR, ENVIRONMENT, ANTI-CORRUPTION (2004). 
labor and civil society organizations, to promote human rights, labor standards, and environmental sustainability within global corporate spheres of influence.

Based in part on human rights principles already universally endorsed by governments, the Compact aims to reflect the type of global society to which the international community has already agreed. The Compact encompasses ten principles drawn from the Universal Declaration of Human Rights, ${ }^{143}$ the International Labor Organization's Declaration on Fundamental Principles and Rights at Work, ${ }^{144}$ the Rio Declaration on Environment and Development, ${ }^{145}$ and the U.N. Convention Against Corruption. ${ }^{146}$ The Ten Principles of the Global Compact include:

Human Rights:

Principle 1. Businesses should support and respect the protection of international human rights within their sphere of influence; and

Principle 2. Make sure they are not complicit in human rights abuses.

Labor:

Principle 3. Businesses should uphold the freedom of association and the effective recognition of the right to collective bargaining;

Principle 4. The elimination of all forms of forced and compulsory labor;

Principle 5. The effective abolition of child labor; and

Principle 6. The elimination of discrimination in respect of employment and occupation.

Environment:

Principle 7. Businesses should support a precautionary approach to environmental challenges;

143. UDHR, supra note 102

144. International Labour Organization, ILO declaration on fundamental principles and rights at work and its follow-up, Geneva: ILO (June 1998), available at http://www.ilo.org/declaration/the declaration/textdeclaration.

145. Rio Declaration on Environment and Development, 31 I.L.M. 874 (1992); see also, Agenda 21: Program of ACtion for Sustainable DeVelopment, Rio de Janeiro, SESSion, PLANNING MEETING U.N. Doc. A/CONF. 151/26 (1992).

146. United Nations Convention Against Corruption, 31 October 2003, 43 I.L.M. 37 (2004). 
Principle 8. Undertake initiatives to promote greater environmental responsibility; and

Principle 9. Encourage the development and diffusion of environmentally friendly technologies.

\section{Anti-Corruption:}

Principle 10. Businesses should work against corruption in all its forms, including extortion and bribery. ${ }^{147}$

Specifically, companies participating in the Compact are asked to embrace, support, and enact-within their sphere of influence - these ten core values. ${ }^{148}$

Of particular importance to articulating what communities can properly demand from corporations, the first two principles address human rights principles and provide: (1) businesses should support and respect the protection of internationally proclaimed human rights; and (2) businesses should make sure that they are not complicit in human rights abuses. ${ }^{149}$ Under the Compact, a participating corporation's human rights commitment extends as far as its reasonable capability to influence events.

The "support and respect" provision of Principle 1 provides that corporations should refrain from any act or omission that would violate human rights or encourage or assist others in the commission of such violations. ${ }^{150}$ U.N. commentary on the Compact recognizes that clarification of corporate responsibilities will often depend on the particular context in which a corporation is operating, as well as upon the relationship it maintains with others in that context. ${ }^{151}$ The "sphere of influence" concept that provides that corporations should assess the influence they possess and design their human rights protection measures accordingly captures this concern. ${ }^{152}$ The scope of the commitment made by participating corporations is limited to the corporation's own sphere of influence.

While this "sphere of influence" concept is not clearly defined by international human rights law, commentary by the U.N. Office of the High Commissioner for Human Rights asserts that a corporation's sphere

147. Raising the Bar, The U.N. Global Compact: A Primer ON THE PRINCIPLES (Claude Fussler, Aron Cramer, \& Sebastian van der Vegt eds., 2004).

148. OfFice of the High COMmissioner for HuMAN Rights, Briefing PAPER ON THE Global Compact and Human Rights: Understanding the Sphere of Influence and COMPLICITY 15 (2004).

149. Id.

150. RAISING THE BAR, supra note 147.

151. Id.

152. $I d$. 
of influence "will tend to include the individuals to whom the corporation has certain political, contractual, economic, or geographic proximity." 153 Therefore, a corporation may have substantial influence not only on its own employees, but also on suppliers and consumers. Every corporation has some sphere of influence: "the larger or more strategically significant the company the larger that company's sphere of influence is likely to be." 154 The Compact's commitment to respect and support human rights and avoid complicity extends to all those who are in a corporation's sphere of influence, understanding, however, that "the extent of a company's ability to act on its human rights commitment may vary depending on the human rights issues in question, the size of the company, and the proximity between the company and the (potential) victims and the (potential) perpetrators of human rights violations." 155

The concept of "complicity" in Principle 2, according to commentary from the Office of the High Commissioner for Human Rights, means that a company is participating in or facilitating human rights violations committed by others. These "others" may be state governments, rebel or resistance groups, or another company or individuals. Thus, "a company is complicit in human rights abuses if it authorizes, tolerates, or knowingly ignores human rights abuses committed by an entity associated with it or if the company knowingly provides practical assistance or encouragement that has a substantial effect on the perpetration of human rights abuse." ${ }^{\prime 156}$ While the company need not engage in the abuse, its assistance or encouragement is such that, without the corporation's participation or facilitation, the abuses most probably would not have occurred to the same extent, or in the same way. Like the sphere of influence concept, the concept of complicity has not yet been fully elaborated under international law, but even where complicity may not be legally proved, public opinion may condemn a corporation seen to be complicit.

In sum, Compact partners are urged to consider the nature of the human rights abuses committed in the country and how the company's activities relate to those abuses. It is often possible to assess whether the pattern of human rights violations in a given country intersects with some aspect of the firm's operations. Companies participating in the Compact are encouraged to incorporate the Compact and its principles into their business strategy and operations.

As a procedural matter, the Compact is a network of the Global Compact Office in New York and six other U.N. Agencies: the Office of

153. OFFICE OF THE High COMMISSIONER FOR HUMAN RigHTS, supra note 148, at 17 n.10.

154. Id.

155. Id. at n. 11 .

156. Id. at 19. 
the High Commissioner for Human Rights; the U.N. Environment Program; the International Labor Organization; the U.N. Development Program; the U.N. Industrial Development Organization; and the U.N. Office on Drugs and Crime.

To participate in the Compact, a company sends a letter from the CEO, endorsed by its board, to the U.N. Secretary-General expressing support for the Compact and its principles. The corporate participant is then expected to publish an annual report on its progress to demonstrate implementation of the principles as a "communication on progress" tool to "demonstrate implementation through public accountability." 157 Because the Compact has elected a voluntary, rather than a legally binding, approach, it emphasizes a "best practices" approach. Accordingly, the Global Compact Office encourages participating corporations to join regional networks, dialogues, and learning partnership projects designed to support Compact implementation in a local context where the company and other Compact stakeholders can take an active role. Businesses are invited to develop and share examples of corporate practices, experiences, and lessons learned with membership and the public on the Compact website.

The U.N. maintains that the Compact is a wholly "voluntary corporate citizenship initiative." 158 Compact participants are assured:

The Global Compact is not a regulatory instrument-it does not "police," enforce or measure the behavior or actions of companies. Rather, the Global Compact relies on public accountability, transparency and the enlightened self-interest of companies, labor and civil society to initiate and share substantive action in pursing the principles upon which the Global Compact is based. ${ }^{159}$

Instead, the core of the Compact is presented as a "learning forum" for reaching a broader, consensus-based definition of what corporate conduct constitutes "good practices.",

The Compact relies to a great extent on the corporate community's collective desire for cultivating a positive image to advance the Principles. To that end, literature from the Compact Office makes abundantly clear that the Compact is in no way a binding or enforceable agreement.

157. Global Compact Office, Corporate Citizenship in the World Economy: The GLOBAL COMPACt, Human Rights, LABOR, ENVIRONMENT, ANTI-CORRUPTION (2004).

158. Id.

159. Un Global Compact OfFice and the OeCD Secretariat, The Un Global COMPACT AND THE OECD GUIDELINES FOR MULTINATIONAL ENTERPRISE: COMPLEMENTARITIES AND DistinCtive CONTRIBUtions 17 (2005), available at www.oecd.org/dataoecd/23/2/34873 731.pdf.

160. John Gerard Ruggie, Taking Embedded Liberalism Global: The Corporate Connection, in John Gerard RugGie, EMBEDding Global MARKETS: AN ENDURING CHALlENGE 231 (2008). 
While it is still early to assess the success of the Compact process, there are currently thousands of corporations participating in the Global Compact. As of 2010 member companies included Cisco Systems, Deloitte Touche Tohmatsu, DuPont, KPMG, Pfizer, Inc. BASF, Nike, Inc., Starbucks, Coca-Cola Company and Royal Dutch Shell among others. ${ }^{161}$ The De Beers Group of Companies, Novartis, Volvo, Deutsche Bank, Bayer AG and Telefonica and others donated to the Foundation for the Global Compact launched in April 2006 to raise funds to support the work of Compact-related activities. ${ }^{162}$

The Compact still remains in its infancy. At the conclusion of the 2004 Leaders Summit, the Secretary-General called for a strategic review of the Compact and the development of a new governance framework that will transform the initiative from its initial phase of experimentation to one of greater focus, transparency, and sustained impact. Consultations have been convened to consider ways the Compact can give priority and attention to the synergies between the global and local levels of its activities, brand management, and quality assurance, as well as to promoting broader ownership of the initiative by all participants. The Compact is taking on increased importance within the U.N. with the creation of an Inter-Agency Task Team composed of the six participating U.N. agencies. The next phase includes plans for a board to provide strategic and policy advice. The board will be composed of four constituency groups: business, civil society, labor, and the U.N. with differentiated roles and responsibilities.

Because it is not binding, certain members of the activist community who regard industry to be engaged in a big "Bluewash" have criticized the Compact. ${ }^{163}$ Some critics object that the U.N., by figuratively forming such a partnership, is acting at variance with the U.N.'s historical mandate. ${ }^{164}$ For example, the Transnational Resource Action Center ("TRAC") strenuously opposed the Compact. TRAC maintains that an improper signal is sent when the U.N. Secretary-General proclaims a partnership to promote globalization with leading executives from corporations with bad reputations for terrible human rights violations in the

161. A list of Compact participating corporations is available at http://www.unglobalcom pact.org/ParticipantsAndStakeholders/index.html.

162. A list of founding contributors in 2006 is available at http://www.globalcompact foundation.org/contributors-2006.php.

163. David M. Biggie, Bring on the Bluewash: A Social Constructivist Argument Against Using Nike v. Kasky to Attack the UN Global Compact, 14 INT'L Legal PERSP. 6, 9 (2004).

164. Alexis M. Taylor, The UN and the Global Compact, 17 N.Y.L. SCH. J. HuM. RTS. 975, 980-81 (2001). 
developing world. ${ }^{165}$ By acknowledging these corporations as members, these critics argue that the U.N. allows corporations to "Bluewash" their reputation and improve their image merely by virtue of becoming a Compact signatory.

Moreover, there may be room to abuse the "the voluntary approach and vague principles" of the Compact. ${ }^{166}$ Accordingly, other critics from the human rights community object to the Compact's failure to institute enforcement mechanisms. The Compact Office concedes that: "the question of what to do with companies who do not show 'good faith' in their dealings with the Global Compact . . . has not as yet been truly resolved." "Still other organizations have criticized the Compact's failure to establish methods for monitoring compliance with the Principles. ${ }^{168}$ Essentially, many of these critics would prefer real rules to the Compact's vague voluntarism.

While many corporations have rushed to embrace the Blue, others are more hesitant and concerned about the possible consequences. For example, the Secretary General of the International Chamber of Commerce issued a statement asserting that, while industry bears the responsibility of being "good corporate citizens," corporations do not have to meet the demands usually imposed on governments to ensure that laws are enforced. ${ }^{169}$

In addition to the U.N. Global Compact program, Kofi Annan, in response to requests from the U.N. Human Rights Council to further consider the issues relating to the empire of enterprise, appointed a Special Representative on the Issue of Human Rights and Transnational Corporations and Other Business Enterprises. ${ }^{170}$ Since being named Special Representative in 2005, John Ruggie presented a series of reports to the U.N. Ruggie proposed a conceptual and policy framework to structure conversations on business and human rights. He announced three primary principles: (1) that states possess the duty to protect against human rights abuses by third parties, including industry; (2) that corpora-

165. See Kenny Bruno \& Joshua Karliner, Transnational Resource Action Center, Tangled Up in Blue: Corporate Partnerships at the United Nations, CORPWATCH, Sept. 1, 2000, available at http://www.corpwatch.org/article.php?id=996 (last visited April 28, 2010).

166. Biggie, supra note 163 , at 12 .

167. Id. at 11 (citing A GUIDE TO THE GlOBAL COMPACT: A PRACTICAL UNDERSTANDING OF THE VISION AND NINE PRINCIPLES, available at http://www.cosco.com/en/pic/research /7573381391844063.pdf).

168. Id.

169. Taylor, supra note 164 , at 982.

170. Press Release, Secretary General, Secretary-General Appoints John Ruggie of United States Special Representative on Issue of Human Rights, Transnational Corporations, Other Business Enterprises, U.N. DoC. SG/A/934 (July 28, 2005), available at http:/www.un.org/News/Press/ docs/2005/sga934.doc.htm. 
tions possess the responsibility to respect human rights; and (3) that effective remedy is warranted for those who rights are violated. ${ }^{171}$

\section{REVISITING BERLE'S VISION: LESSONS FROM THE LEGACY OF THE MODERN CORPORATION}

Berle's scholarship may not be an immediately obvious source for insights into international law, but after a review of the human rights issues raised by corporate conduct abroad, it becomes more apparent that in certain respects analogies exist between the problems of the past and the present.

Although Berle wrote to address the problems associated with economic risks to individuals due to the unconstrained power of corporate control, his concerns can be extended into and apply to the sphere of the social and risks to communities as well. Since Berle's writings were among the first commentaries on corporate law to speak to the larger concern of the impact of the corporate system on society, the problems he identified with respect to corporate power would appear to apply in a global context as well.

Dalia Tsuk's discussion of The Modern Corporation and Private Property summarizes the legacy of Berle's work as one in need of rescue because, since its publication: "corporate law scholarship has been obsessed with its exegesis of the potential economic risks associated with the separation between ownership and control in large business corporations." 172 Berle's early writings were interpreted as advancing shareholder supremacy. This interpretation collapsed into a narrower notion of shareholder interest; an interest limited to short-term profit maximization to the exclusion of the broader societal concerns which were also important in his book. ${ }^{173}$ As a result, Tsuk argues:

The Legal Community has made corporate law, specifically the rules applicable to the allocation of power among directors, executives and shareholders ineffective as a means of regulating corporate power . . . over the course of the past century, corporate law has been used first to legitimate corporate power and then to exempt those exercising it from liability. ${ }^{174}$

171. The Special Representative of the Secretary-General on the Issue of Human Rights and Transnational Corporations and Other Business Enterprises, John Ruggie, Report of the Special Representative of the Secretary-General on the Issue of Human Rights and Transnational Corporations: Protect, Respect and Remedy: A Framework for Business and Human Rights, delivered to the Human Rights Council, Eighth Session, U.N. Doc. A/HRC/8/5 (Apr. 7, 2008).

172. Tsuk, supra note 27, at 1910.

173. Id.

174. Id. 
This application is profoundly problematic in the context of corporations operating in developing states, in countries with repressive regimes, or in countries that are otherwise not accountable to the people living within its borders.

As the reach of the corporation expands, it is appropriate to revisit Berle's writings in the context of economic globalization and the rise of the modern international human rights regime. It is especially important to remember that Berle's main contribution was his normative message, principally, "that corporate power be exercised to benefit the community at large." 175

Berle believed that the community could make claims of enterprise and, as the community came to more clearly craft and articulate its demands, corporate power would have to concede in some measure and satisfy the demands of the public. The problem of power and how to align business conduct in a way that is responsible to shareholders, or ultimately to respect human dignity and the environment, is a persistent one. Today, we witness unprecedented advocacy, adjudication activities, and efforts to articulate the demands of people around the world.

Accordingly, we still look to Berle so many years later and still have much to learn. The Modern Corporation and Private Property was visionary for recognizing the potential perils of concentration of corporate power due to the separation of ownership from control, for predicting the rise of an empire of economic enterprise comparable to the state in its power, and finally for imagining a new concept for the corporation and declaring an expanded scope of corporate interests.

In The Modern Corporation and Private Property, Berle identified power disconnected from control. This disconnect-combined with the irresponsible or amoral exercise of power-is an underlying condition that allows corporate complicity in human rights violations to occur. The problem is particularly acute where states are weak, failed, in conflict, or corrupt. Yet corporate law remains mostly concerned with internal governance and focuses less on the external impacts these forms of corporate governance create, or the broader social environment in which the corporation conducts business. As advocacy groups direct attention to the effects of corporate action, corporate legal scholars would do well to consider what contributions corporate law can make to ameliorate, rather than exacerbate, human rights violations and environmental problems.

Berle's The Modern Corporation and Private Property provides scholars working on human rights - who have traditionally focused primarily on government violations-with insights because its primary 
teaching concerns the power of private actors. Entities, which until very recently were beyond the discipline's core concerns, are explored in great detail. At the highest level of generality, the core study of international law is also an inquiry into power. The power of the sovereign now shares space with the power of the economic empire that Berle envisioned. The protection of human rights and the environment is entirely dependent on the responsible exercise of power wherever it resides.

In light of the alleged corporate complicity in violations of international human rights, it is an interesting exercise to ask what Berle would have advised. How might Berle's concerns about the concentration of power and ways to control power have altered the outcomes or expanded choices of the pharmaceutical industry in South Africa, the extractive industry's conduct in Nigeria, or the internet service providers in China, when met with claims from the community challenging their complicity in human rights violations?

The early debate between Berle and Dodd is instructive because it considers which avenue for constraining corporate power would be best to avoid the abuses described above, and to align corporate conduct with respect for human rights.

Berle looked to the shareholder community, in the form of the investing public, to represent the interests of the public, while Dodd maintained that management would best hold in trust the interests of the community. Today a more pluralistic path is the proper approach to protecting community interests in a global economic system. Therefore, the avenues offered by both Berle and Dodd must be taken. Norms respecting the interests of the community-when internalized by business leaders as well as the investing public conversations - will move corporate social responsibility forward instead of in cyclical circles of academic and advocacy attention dependent on passing trends.

The shareholder community can be a positive influence provided it is conscious, active, and informed. ${ }^{176}$ Management is also a potentially positive influence, but must be cognizant of the potential problems its business decisions may cause. ${ }^{177}$ Management must also communicate with other constituencies that its business decisions might affect and consider these other interests. There are forward-thinking corporate executives. For example, the CEO of Seventh Generation named his company

176. See Bruno Amann, Jerome Caby, Jacques Jaussaud \& Juan Pineiro, Shareholder Activism for Corporate Social Responsibility: Law and Practice in the United States, Japan, France and Spain, in The New Corporate AcCountability: Corporate Social ReSPONSIBILITY and the LAW 336 (Doreen McBarnet, Aurora Vioculescu \& Tom Campbell eds., 2007).

177. See Lawrence E. Mitchell, The Board as a Path Toward Corporate Social Responsibility, in THE New Corporate ACCOUNTABILITY: Corporate SOCIAL ReSPONSIBILITY AND THE LAW 279 (Doreen McBarnet, Aurora Vioculescu \& Tom Campbell eds., 2007). 
after the decision making processes taken by Native American communities: decisions are made after taking into account the impact it may have on the community's next seven generations, appreciating that all are connected.

For Berle, it was the lack of connection that gave rise to the risk of abuses he feared. As Berle's biographer stated, "entrepreneurial competition had given way to depersonalized monopoly."178 In a passage in The Modern Corporation and Private Property, Berle references Walter Rathenau's writings on the depersonalization of the publicly traded corporation, he despaired:

$[\mathrm{N}] \mathrm{o}$ one is a permanent owner. ... This condition of things signifies that ownership has been depersonalized .... The claims to ownership are subdivided in such a fashion, and are so mobile that the enterprise assumes an independent life, as if it belonged to no one. ... The depersonalization of ownership, the objectification of enterprise, the detachment of property from the possessor leads to a point where the enterprise becomes transformed. . . . ${ }^{179}$

The law is left with powerful entities that possess legal personality but are lacking in identity or a sense of connection to community. Yet, there are corporations for whom "identity," as such, is central.

At Google, "Don't Be Evil" is something of a "cultural rallying call." 180 The founders of Google made an effort to retain their personal imprint on the corporation when it went public. The founders retained $37.6 \%$ of stock voting power and the executive management retained $61.4 \%$, thereby leaving investors "little ability to influence strategic decisions through voter rights," because the founders did not want to be at the mercy of the market and shareholder profit maximizing. In their letter to potential investors, Google warns that profits may be lower than those of corporations who are rewarded in the market for short term tactics because they intend to maintain focus on the long term and resist pressure to meet quarterly market expectations. So insulated, Google states that it will adhere to their one main principle: "Don't Be Evil." Initially, "Don't Be Evil" applied to how Googlers should treat each other, but came to be associated with how Google should be in the world. The Owner's Manual for Google Shareholders explains:

178. SCHWARZ, supra note 11 , at 60

179. BERLE \& MEANS, supra note 1 , at 352.

180. John Battelle, The Search: How Google and Its Rivals Rewrote the Rules of BUSINESS AND TRANSFORMED OUR CULTURE 138-39 (2005); JESSICA LIVINGSTON, FOUNDERS AT WORK: STORIES OF STARTUPS' EARLY DAYS 169 (2007). 
Google is not a conventional company. We do not intend to become one... . Our goal is to develop services that significantly improve the lives of as many people as possible. In pursuing this goal, we may do things that we believe have a positive impact on the world, even if the near term finical returns are not obvious. ... We will live up to our "don't be evil" principle. ... ${ }^{181}$

\section{CONCLUSION}

Adolf Berle's contribution to the field of corporate law can inform current debates over the alleged complicity of multinational corporations in international human rights violations. Berle offered a perspective on the rise of an empire of business enterprise that envisioned allowing those within industry's realm to demand that industry be accountability to society. In international law there is little theory to account for how to treat an international non-state actor that may be as powerful as member states in the international community. Berle's insights teach that it may be appropriate to treat the multinational corporation as an entity that must-like a sovereign - bear some responsibility for societal wellbeing. Consciously conducting business across borders thus requires being cognizant of the concerns of the communities that the corporation's conduct affects. With respect to whether ownership or control is better suited to manage the social risks associated with business operations, it is becoming clear that both will be called upon to consider the demands of increasingly vocal communities.

Corporate efforts not to be "evil" are indeed admirable, but corporate law has left society with an institution that has been systematically rendered amoral. Perhaps we will see the workings of still another revolution in the corporate system. As industry imposes upon itself obligations that the law has not yet required through corporate social responsibility initiatives in response to community pressures, we may see a revolution of corporate conduct. An interdisciplinary corporate legal scholarship that comes to give greater consideration to how communities shape and shift normative expectations of power may adjust the present concept of the corporate form and better align corporate conduct with larger societal interests in the future.

181. Google Inc., Letter from the Founders: “An Owner's Manual” For Google's Shareholders, Amendment No. 9 to Form S-1 Registration Statement, available at http://investor.google.com/ corporate/2004/ipo-founders-letter.html. Arguably, Google's recent public reproach of the Chinese government over censorship policies is the necessary consequence of cultivating a public identity opposed to evil. See, e.g., Jason Dean, Geoffrey A. Fowler \& Aaron Back, China Threatens Google: Beijing Raises Tension in Censorship Spat: 'You are Unfriendly and Irresponsible', WaLl ST. J., Mar. 13, 2010, at A1. 